\title{
How the role of ATM technology encourage financial efficiency on Madura villagers?
}

\author{
Alifah Rokhmah Idialis; Sariyani; Ayu Delawati Prasetyoningtyas*; \\ Roechainy Kartika Ulfa
}

Department of Economics, Faculty of Economics and Business, Universitas Trunojoyo Madura, Indonesia

*To whom correspondence should be addressed. Email: ayudellawapra@ gmail.com

\begin{tabular}{|l|l|l|l|l}
\hline DOI: & Received: & Revised: & Accepted: & Published: \\
10.22437/ppd.v9i1.10629 & 30.09 .2020 & 12.04 .2021 & 19.04 .2021 & 30.04 .2021 \\
\hline
\end{tabular}

\begin{abstract}
Nowadays, the necessity and utilization of Automatic Teller Machine (ATM) technologies increase in rural areas. Financial technology became a crucial thing and created efficiency in their activities. Some previous research uncovers technology that could create efficiency in the economy, including financial technology. This paper, interest in investigating and detect how ATM technology establishes financial efficiency on villagers. This research was conducted in rural communities on the island of Madura, Indonesia. This study uses SFA (Stochastic Frontier Analysis) model to estimate technical efficiency. This research found out that ATMs in rural communities on Madura Island produce highly financial efficiency. It proved that the villagers in Madura need ATM technology for carrying out their economic activities.
\end{abstract}

Keywords: Automatic Teller Machine, Financial efficiency, Stochastic Frontier Analysis, Villagers

JEL Classification: G21, G50, O33

\section{INTRODUCTION}

The development of financial technology in Indonesia in the latest decade grows very high. The rapid development of financial technology, one of them is automatic teller machine (ATM) technology. Central Bank of Indonesia was recorded the average number of ATM cardholders during 2019 at 9.3 billion users (according to the report of transaction tool use card).

The development using ATM technology has increased awareness from the Indonesian society to use ATM technology growing fast. The necessity for ATM as supporting economic activities is needed, mainly for the people that stay in the rural area. The rapid technology development, both direct and indirect, also affects the village community's mindset and habits. Formerly, they perform financial transactions by coming directly to the bank, but now they are given easy to perform financial transactions and the bank through atm. The ATM technologies were given to the villagers for ease and smoothness in economic activities.

Wulan (2017) figures out ATM holders, which positively and significantly impact the economy. Liaou et al. (2019) prove that there is the involvement of the internet against financial efficiency. Li et al. (2018) reveal an important role of technological innovations in the industrial sector. If it is associated with this discovery, this can be 
concluded technological innovations in the financial sector will also create efficiency. Asongu et al. (2019) uncover the important role of information technology and communication to create financial efficiency. Besides building financial efficiency, financial technology also changes people's mindset, particularly of a village community (Prawirasasra, 2018). Internet used properly also helps to create financial efficiency (Botti et al., 2014). Another research found out financial efficiency also came from good governance and professional treatment of a financial institution (Yobe et al., 2020; Botti, 2014). Even Sufian (2004) revealed that good managerial and governance in financial institutions should produce efficiency.

The research's main focus is to identify and detect the role of ATM technology in financial efficiency for villagers in Madura. Whether with ATM technology give a significant impact on the smooth and convenient activities which Madura villagers do. Whether by financial technology, Madura villagers on their financial activities become more efficient. To prove that question then will be used the Stochastic Frontier Analysis (SFA) method.

\section{LITERATURE REVIEW}

\section{Financial efficiency and technology}

In these decades, technology became a crucial thing in over the world. Nearly all activities in this world using technology, especially to create efficiency and effectiveness. Technology gives simplicity and smoothness to human activities, primarily financial activities.

Nowadays, the role of technology in finance is very important. Using technology in financial activity would make it more efficient and effective. Saksonova (2017) verified that financial technology does not give satisfaction, comfort, fastness, and security in Latvia Country. That is because Latvia is developing countries and it does not ready through financial technology.

Wulan (2017) found out that financial technology developed in Indonesia, such as credit cards, ATM cards, and computer mainframe banks, has increased significantly. This result has a positive impact on the Indonesian economy. It provides a significant positive impact on the Indonesian economy. Another finding of this study is that Indonesian financial technology still needs technology maturity, resources, users, and regulations.

Different outcomes find that financial technology development negatively impacts the banking industry (Purnomo \& Khalda, 2019). In addition to being a barrier to banking, financial technology should also be an opportunity for banks. Financial technology also has social impacts, such as changing the mindset of conventional financial institutions (Prawirasasra, 2018). Another result reveals the need for optimization by intervention regulation to maximize financial technology.

Previous research proved that technology could produce efficiency. The technology injects into the financial sector will build financial efficiency. Liaou et al. (2019) discovered there an impact of the internet on financial efficiency. The internet has a role in promoting regional financial resources and making advanced technology. Li et al. (2018) show innovation in technology which can produce efficiency in the industrial sector, mainly manufacturing.

Similarly, the role of technology in the financial system is very important to build financial efficiency. Information technology and communication positively impacted increasing information and financial transactions in 53 countries in Africa's Continent (Asongu et al., 2019). Their result also discovers that information technology and communication produce financial efficiency, particularly efficiency on financial intermediaries. Using the DEA-Malmquist model, Li and $\mathrm{Wu}$ (2016) prove large 
fluctuations to financial encourage efficiency.

Financial efficiency is one of the determinants of economic stimulus. Healthy finances were demonstrated by the level of efficiency achieved. Efficiency is also used as a benchmark for the health of financial institutions. Besides technology having an important role in financial efficiency, good governance and professional management have also driven financial efficiency. The oldest financial institution like cooperative becomes more efficient than new cooperative (Yobe et al., 2020). A cooperative or financial institution with long experience tends to have good and professional management. Good governance becomes one of the key successes to create financial efficiency. Botti et al. (2014) suggest that good governance and proper usage of the internet create efficiency in financial reporting. Nourzad (2014) uncovers the development of financial intermediaries and equity markets to increase efficiency. Sufian's (2004) investigation shows a positive and significant relation to financial institutions' non-bank that is more efficient in a managerial manner.

\section{Financial efficiency and rural area}

In the modern era, the important role of finance becomes one of the main factors driving the economy at the rural level. The financial role also improves the welfare of villagers - nearly all of their activity depending on the financial sector. Generally, rural areas' people in developed countries are already aware of the financial technologies as a form of financial inclusion.

Nevertheless, in developing countries, financial technologies still lack the facilities and infrastructures that support financial inclusion, so difficult to create. The financial technologies in China, a high level of economic growth, is quite helpful for rural communities, primarily for farming credit (Turvey and Xiong, 2016). Their findings recording more than $2 \%$ farm credit were distributed to the village. Financial products have a more efficient and effective tendency when is given to women (Arnold \& Gammage, 2019). Financial products such as the economic empowerment and rescue of the financial institution have effective and efficient when managed by women, particularly in the village (Robert, 2015). Women have a tendency professional in planning and financial management than men, although the income earned is smaller (Tharp et al., 2019). Arestis (2006), using DEA analysis, represents financial deepening and financial development, which positively affects production efficiency.

\section{Stochastic Frontier Analysis (SFA)}

Efficiency becomes important in the financial industry. Some previous research finds out efficiency on financial wich comes from technology usage. To detect, identify, and analyze exit or not efficiency on financial uses, the Stochastic Frontier Analysis (SFA) approach measures efficiency value.

SFA is one of the method and analysis instruments to measure the level of efficiency. SFA method built based on regression model theory that Battese \& Coelli found in 1992. SFA is linear programming used to measure the performance of an organization's efficiency by using the DMU (Decision Making Unit) (Eni et al., 2020). A Decision Making Unit (DMU) is an entity that uses inputs to produce outputs (Hassan, 2018). Another definition of SFA is a statistical analysis technique used to estimate the cost of production function in an economy by considering the inefficiency of companies. This definition and strengthened by Coelli (2005) explain that two types of functions can measure the efficiency with the SFA method, namely the production function and the cost function. The SFA model could be written the equation 1:

$$
\begin{aligned}
& Q_{i}=\beta_{0}+\beta_{1} X_{i}+v_{i}-u_{i} \\
& \text { Description: } \\
& \mathrm{Q}_{\mathrm{i}} \text { : dependent variable (output) }
\end{aligned}
$$


$\beta_{0}:$ constanta

$\beta_{1}$ : coefficient of the independent variable

$\mathrm{X}_{\mathrm{i}}$ : independent variable (input)

$\mathrm{v}_{\mathrm{i}} \quad$ : normally residual or random factors that cannot be controlled

$\mathrm{u}_{\mathrm{i}}$ : technical inefficiency or random factors that can be controlled

\section{METHODS}

We are using primary data which can collect directly from Madura villagers. The Sampling technique uses the random sample cluster method, which is randomly generated by area, without any special classification such as social strata, age, education, etc.

The number of samples was 200 respondents, consisting of 50 respondents of each regency in Madura Island (Sumenep, Pamekasan, Sampang, and Bangkalan). Data sources are directly obtained through interviews and refilling of the questionnaires.

The questionnaire question includes two parts: 1) The respondent's identity form of the name, gender, age, and occupation; 2) Instrument efficiency of ATM uses the form of ATM usage period, the use of ATM menu of pin chance, transfer, withdrawal, payment, inquiry. Two other questions are regarding security and the ease of respondents accessing ATM.

This study uses a parametric approach with Stochastic Frontier Analysis (SFA) to detect and analyze the financial efficiency. Estimation of Stochastic Frontier Analysis (SFA) models as in the following equations 3:

$P_{1}=\beta_{1} q_{1}+\beta_{2} q_{2}+\beta_{3} q_{3}+\beta_{4} q_{4}+\beta_{5} q_{5}+\beta_{6} q_{6}+\beta_{7} q_{7}+\ldots \ldots+\beta_{n} q_{n}+E_{n}$

Description:

$P_{1}=\log$ Time Period of use ATM

$q 1=\log$ Pin Change

$q 2=\log$ Transfer

$q 3=$ Log Withdrawal

$q 4=\log$ Payment

$q 5=\log$ Inquiry

$q 6=\log$ Security

$q 7=\log$ Access

$E_{n}=$ error term

Meanwhile, $E_{n}$ is the error term of the function (Zuhroh, 2015). According to Rahaman (2016) $E_{n}$ is described by Collin's theory which is error terms in the SFA model consists of two components as in the following equation 4:

$E_{n}=V_{t}-U_{t}$

Description :

$V_{t}=$ Random factors that cannot be controlled.

$U_{t}=$ Random factors that can be controlled.

From the equation above, we get an error technical as an efficiency indicator. To measure the level of efficiency, this can be calculated using the value of $U_{t} . U_{t}$, which indicates the efficiency value of the production output. $U_{t}$ is a level of technical efficiency that has a value between 0 and 1. To simplify the process of analysis, technical efficiency is categorized into three namely:

1. Low efficiency, with a technical efficiency less than 0.5 ;

2. Medium efficiency, with a limit of technical efficiency of 0.5 to 0.8

3. High efficiency, with a limit of technical efficiency of more than 0.8 


\section{RESULTS AND DISCUSSION}

\section{Profile of respondents}

Various age from respondent's between 25 until 70 years old. The profile exposing respondents' gender consists of $104(52,00 \%)$ males and $96(48,00 \%)$ females. The majority of ATM user is male. It proved that the male role in the family still dominant in finance facilitation rather than female. Madura society is still patriarchal, where males provide and determine a treasury within households.

Based on employment status, $79.50 \%$ of respondents worked, and $20.50 \%$ were not working (were housewives). Specifically, homemakers became a job and devotion for a woman in the village. In Madura, especially thick with religious teachings, they still believe to be selfless housewives is an obligation that later creates prosperity for their family.

Of the total respondents who are working status, almost half $(49.00 \%)$ are entrepreneurs. The rest are those who work as government employees, private employees, farmers, and others. It showed that the profession of the majority of villagers in Madura is an entrepreneur. This discovery opens up new information that there is a shift in profession from farmers to entrepreneurs in the village. The development of financial technology also has a significant impact on the change of occupations in the village. Refers to this finding concludes that the average Madura society is an entrepreneur as a majority profession.

\section{Stochastic Frontier Analysis}

The equation above is estimated and tested using the Stochastic Frontier Analysis approach. The first result provides a descriptive statistic that is shown in Table 1. Meanwhile, the result estimation of the SFA model uncovers in Table 1. The Stochastic Frontier equation can be rewritten as follows:

$P_{1}=0.060 q_{1}+0.145 q_{2}+0.182 q_{3}+0.025 q_{4}+0.062 q_{5}+0.665 q_{6}+0.148 q_{7}-2.824-2.562$

Based on the results of the SFA regression, all of the explanatory variables significant to the dependent variable. It is further strengthened by the probability value of Wald Chi-Square 0.000 less than the level of significant 5\%. According to the revealed level table of transfer has a significant impact on the period of using ATM level. It is also evidenced by the probability value of z-statistic 0.078 less than $10 \%$ significant level. Each increase of $1 \%$ on transfer level will rise $0.145 \%$ of using ATM period. As well as the level of security has a significant effect on the period of use ATM level. The impact of the level of security is amplified by the probability value of $\mathrm{z}$ statistic 0.000 less than $5 \%$ significant level. Rising of $1 \%$ on security level will rise $0.665 \%$ of Period of use ATM.

Table 1. The estimation of Stochastic Frontier Analysis (SFA)

\begin{tabular}{lccl}
\hline \multicolumn{1}{c}{ Independent Variables } & Coefficient & z-statistic & $\mathrm{P}>\mathrm{Z}$ \\
\hline Log Pin change (Q1) & 0.060 & 0.98 & 0.329 \\
Log Transfer (Q2) & 0.145 & 1.76 & $0.078^{* *}$ \\
Log withdrawal (Q3) & 0.182 & 2.26 & $0.024^{*}$ \\
Log payment (Q4) & 0.025 & 0.38 & 0.703 \\
Log Inquiry (Q5) & 0.062 & 0.76 & 0.449 \\
Log Security (Q6) & 0.665 & 7.27 & $0.000^{*}$ \\
Log Access (Q7) & 0.148 & 1.56 & 0.119 \\
lnsig2v & -2.824 & 12.62 & $0.000^{*}$ \\
lnsig2u & -2.562 & 8.90 & $0.000^{*}$ \\
Wald chi $^{2}$ (7) & 1369.74 & \\
Prob > chi & & \\
* $^{2}$ significant at the 5\% level, **significant at the 10\% level & &
\end{tabular}


The level of withdrawal has an influence significantly on the period of use ATM. It is enhanced by the probability value of $\mathrm{z}$-statistic 0.024 less than $5 \%$ significant level. One percent increase on withdrawal level will increase $0.182 \%$ of the period of use ATM level. This discovery reveals that transfers, withdrawals, and security are commonplace by users of ATM technology. Referring to the results of estimating can be concluded that the role of ATM technology as a tool of ease in conducting financial transactions has been proven

\section{Efficiency analysis}

The measurement of efficiency score is determined by several classifications (Andhyka, 2017). According to Junaedi (2016) about technical simultaneous efficiency analysis uses the stochastic frontier production function model. The efficiency index value of the analysis results can be categorized as efficient in using production inputs if the value is almost and close to 1 . The categories used in research are highly efficient when they have a value of more than 0.90 if its value is between 0.70 to 0.89 , which means quite efficient, while the value is smaller than 0.70 , which means inefficient.

Table 2 finds out that the average value of the technical efficiency was 0.813 . It shows that most users have quite efficient ATM technology that has been used and provided. Furthermore, most (78.00 percent) of ATM users have a technical efficiency value that is highly efficient (value $=0.999$ ) and quite efficient (value $=0.750$ ). Only 22.00 percent of them experienced inefficiency (values 0.499 and 0.249 ).

Table 3. The average and distribution of technical efficiency value

\begin{tabular}{lccc}
\hline No & Value of technical efficiency & Description & $\%$ respondents \\
\hline 1 & 0.999 & highly efficient & 51.50 \\
2 & 0.750 & quite efficient & 26.50 \\
3 & 0.499 & inefficient & 17.50 \\
4 & 0.249 & inefficient & 4.50 \\
\hline \multicolumn{4}{c}{} \\
\hline \multicolumn{4}{l}{ Total } \\
\hline
\end{tabular}

From this evidence can conclude mostly Madura villagers get high efficiency from ATMs usage. ATM technology gives them ease and effectiveness to activity that is related to economic and financial. This result also reinforces that ATM technology significantly affects financial efficiency in rural areas (based on average technical efficiency number 0.813). These findings are supported by previous research, which reveals which the role of banking can create financial efficiency (Steward et al., 2017). The results in this study are in line with research Mishkin and Strahan (1999), which states that the development of financial technology reduces transaction costs and asymmetric information's, improves efficiency in the financial system, and changes the structure of the financial system

\section{CONCLUSIONS AND RECOMMENDATIONS}

\section{Conclusions}

On average efficiency value of ATM usage, Madura villagers are quite efficient. More than half of ATM users get ease and efficiency from the use of ATM. It provides evidence that ATM technology benefits Madura villagers' financial activities, partially supporting their economy.

This study founds out almost all ATM menus which they often use in conducting financial transactions. The discovery shows that Madura, as an area with low economic growth and minimal social welfare, also requires financial technology to support financial effectiveness and efficiency. 


\section{Recommendations}

Policymakers should build more ATM facilities, support financial modernization, and facilitate and facilitate rural and remote communities' activities. Theoretically, this research still requires further studies in various places to strengthen the evidence that rural communities need ATM technology. Other research also needs to be carried out to analyze the relationship between the characteristics of rural communities and the need for ATM services.

\section{REFERENCES}

Andhyka, B. N. (2017). Penggunaan BUKU dan Kepemilikan dalam Menganalisis Efisiensi Perbankan di Indonesia. Al Tijarah, 3(2), 1-22.

Arestis, P., Chortareas, G. \& Desli, E. (2006). Technical efficiency and financial deepening in the non-OECD economies. International Review of Applied Economics, 20(3), 353-373. https://doi.org/10.1080/02692170600736151

Arnold, J., \& Gammage, S. (2019). Gender and financial inclusion: the critical role for holistic programming. Development in Practice, 29(8), 965-973. https://doi.org/10.1080/09614524.2019.1651251

Asongu, S.A., Anyanwu, J.C. \& Tchamyou, V.S. (2019). Technology-driven information sharing and conditional financial development in Africa. Information Technology for Development, 25(4), 630-659. https://doi.org/10.1080/02681102. 2017.1311833

Battese, G.E., \& Coelli, T.J. (1992), Frontier production functions, technical efficiency and panel data: With application to paddy farmers in India. Journal of Productivity Analysis, 3(1-2), 153-169.

Botti, L., Boubaker, S., Hamrouni, A., \& Solonandrasana, B. (2014). Corporate governance efficiency and internet financial reporting quality. Review of Accounting and Finance, 13(1), 43-64. https://doi.org/10.1108/RAF-11-20120117

Coelli, T. (1996). A Guide to FRONTIER Version 4.1: A Computer Program for Stochastic Frontier Production and Cost Function Estimation. CEPA Working paper 96/07, Department of Econometrics, University of New England, Australia.

Coelli, T., Rao, D., O’Donnell, C. \& Battese, G. (2005) An Introduction to Efficiency and Productivity Analysis. 2nd ed., New York: Springer.

Dogan, N. O., \& Tugcu, C. T. (2015). Energy efficiency in electricity production: A data envelopment analysis (DEA) approach for the G-20 countries. International Journal of Energy Economics and Policy, 5(1), 246-252.

Eni, Y., Enjelia, L.T., Putri, J.M. \& Sari, F.N. (2020). The Efficiency of Rice Production Analysis in The Western Part of Indonesia By Using Stochastic Frontier Analysis Method ( SFA ). International Journal of Advanced Science and Technology, 29(5), 6154-6165.

Junaedi. (2016). Pengembangan Kapas Rakyat di Sulawesi Selatan. Bandung: CV. Mujahid Press.

Li, H., \& Wu, L. (2016). Analysis of financial support efficiency for China's wind power industry. Energy Sources, Part B: Economics, Planning and Policy, 11(11), 1035-1041. https://doi.org/10.1080/15567249.2016.1185480

Liao, G., Yao, D., \& Hu, Z. (2020). The Spatial Effect of the Efficiency of Regional Financial Resource Allocation from the Perspective of Internet Finance: Evidence from Chinese Provinces. Emerging Markets Finance and Trade, 56(6), 12111223. https://doi.org/10.1080/1540496X.2018.1564658

Mishkin, Fredric S. \& Philip E. Strahan. (1999). What Will Technology Do to Financial Structure?. NBER Working Papers 6892, National Bureau of Economic Research, 
Inc.

Nourzad, F. (2002). Financial development and productive efficiency: A panel study of developed and developing countries. Journal of Economics and Finance, 26(2), 138-148. https://doi.org/10.1007/BF02755981

Rahaman, A.A. (2016). Stochastic Frontier Analysis (SFA) of technical efficiency, insights from small holder cotton farmers in the Northern Region of Gama. Global Science Reserch Journal, 4(1), 361-267.

Roberts, A. (2015). Gender, Financial deepening and the production of embodied finance: towards a critical feminist analysis. Global Society, 29(1), 107-127. https://doi.org/10.1080/13600826.2014.975189

Romdhane, S. B. (2013). Impact of information technology on the performance of Tunisian banks: A stochastic frontier analysis with panel data. Asian Academy of Management Journal of Accounting and Finance, 9(2), 95-125.

Sadalia, I., Kautsar, M.H., Irawati, N., \& Muda, I. (2018). Analysis of the Efficiency Performance of sharia and Conventional Banks Using Stochastic Frontier Analysis. Banks and Bank systems, 13(2), 27-38.

Steward, C., Matousek, R. \& Nguyen, T.N. (2016). Efficiency in the Vietnamese banking system: A DEA double bootstrap approach. Research in International Business and Finance, 36, 96-111. https://doi.org/10.1016/j.ribaf.2015.09.006

Sufian, F. (2006). Title The Efficiency of Non-Bank Financial Institutions: Empirical Evidence from Malaysia Centre for Policy Initiatives (CPI). Source International Research Journal of Finance \& Economics, 6, 49-65.

Tharp, D.T., Lurtz, M., Mielitz, K.S., Kitces, M., \& Ammerman, D.A. (2019). Examining the gender pay gap among financial planning professionals: A Blinder-Oaxaca decomposition. Financial Planning Review, 2(3-4), 1-20. https://doi.org/10.1002/cfp2.1061

Turvey, C. G., \& Xiong, X. (2017). Financial inclusion, financial education, and ecommerce in rural china. Agribusiness, 33(2), 279-285. https://doi.org/ 10.1002/agr.21503

Woldmariam, M. F., Ghinea, G., Atnafu, S., \& Groenli, T-M. (2016). Monetary Practices of Traditional Rural Communities in Ethiopia: Implications for New Financial Technology Design. Human-Computer Interaction, 31(6), 473-517. https://doi.org/10.1080/07370024.2016.1139461

Yobe, C.L., Ferrer, S.R.D., \& Mudhara, M. (2020). Measuring the financial efficiency of agricultural cooperatives in South Africa: an application of the Simar-Wilson methodology. Agrekon, O(0), 1-18. https://doi.org/10.1080/03031853.2020. 1761845

Zuhroh, I., Ismail, M. \& Maskie, G. (2015).Cost Efficiency of Islamic Banks in Indonesia - A Stochastic Frontier Analysis. Procedia-Social and Behaviour Science 211. DOI: 10.1016/j.sbspro.2015.11.150.

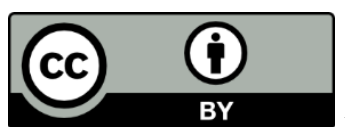

